\title{
Proximal Convoluted Tube
}

National Cancer Institute

\section{Source}

National Cancer Institute. Proximal Convoluted Tube. NCI Thesaurus. Code C33417.

The coiled duct section of a nephron, located between Bowman's capsule and the loop of Henle in the renal cortex, that concentrates the urine. 